\title{
THE RELEVANCE OF THE EUROPEAN CONSUMER PROTECTION LAW FOR THE DEVELOPMENT OF THE EUROPEAN CONTRACT LAW
}

\author{
Francesco A Schurr*
}

This paper deals with the interaction of consumer law and contract law in the European Union. Over the last two decades the European legislature has adopted many legislative measures in the field of consumer protection that were designed to strengthen the single market and to avoid distortion of competition. Thus the European legislature tried to approximate or harmonise consumer protection standards within the European Community and consequently created a new layer of supranational contract law which now coexists with the traditional national contract law regimes. The paper assesses the various types of contract law on the international, supranational and national levels and discusses the problems arising from the fact that the contract law in the European Community is so diverse. Directive 2005/29/EC on Unfair Business-to-Consumer Commercial Practices is discussed as a very prominent recent product of European Community consumer legislation. The paper points out how the development of European consumer law serves as a catalyst for the further development of a genuine European contract law.

Cet article s'intéresse plus particulièrement aux rapports qui peuvent exister dans l'Union Européenne entre le droit de la consommation et celui des contrats. Au cours de ces 20 dernières années, le législateur européen a, de manière répétée, renforcé la protection du consommateur et ce dans le but d'apporter une meilleure cohésion du concept du marché unique tout en respectant les règles de la concurrence.

Dans ce contexte, le législateur européen a essayé de faire coïncider voire d'harmoniser, les différents standards de protection du consommateur avec ceux dégagés par la communauté européenne, finissant ainsi par créer une nouvelle source supranationale en matière de droit des

* Associate Professor for Private Law and Comparative Law at the University of Innsbruck, Austria. Visiting Lecturer, Victoria University of Wellington. 
contrats laquelle coexiste aujourd'hui avec celui en vigueur dans chaque droit national des états membres.

Cet article évalue les différentes règles applicables tant au niveau national qu'au niveau supranational et s'intéresse plus particulièrement aux problèmes liés au grand nombre de textes régissant le droit des contrats dans la communauté européenne.

La directive 2005/29/CE relative aux pratiques commerciales déloyales, une des réformes les plus récentes en matière des droits de la consommation en Europe, sert de fil conducteur à l'auteur qui démontre de quelle manière le développement du droit européen de la consommation a pu servir de catalyseur pour l'apparition d'un véritable droit européen des contrats.

\section{INTRODUCTION}

The association of consumer law and contract law is typical for most legal systems. Accordingly the European Union (EU) member states have traditionally embedded most parts of the consumer law in their contract law. At present the contract law regime in the EU is highly diverse. It is arguable that this legal multiplicity stands in the way of the proper functioning of the European economy and especially of the single market. ${ }^{1}$ On the other hand it is uncertain whether it is worth paying the high price of abandoning the slowly grown legal traditions in order to create a fully harmonised European contract law. Furthermore it is not clear whether the high cost of creating a uniform contract law regime can be outweighed by the money saved through the reduction of transactions costs. ${ }^{2}$

This article begins by scrutinising this puzzling variety of national, supranational, and international contract law regimes. After having determined the status quo of European contract law in general, the European consumer protection policy needs to be evaluated, since the legal documents arising from this policy have broadly encroached on the traditionally grown structures of the member states' contract law regimes. After that there will be discussion of some instruments of consumer protection in the contractual relationship and then focus on selected aspects of the precontractual information duties. The paper will then deal with the new Directive 2005/29/EC on Unfair Business-to-Consumer (B2C) Commercial Practices. ${ }^{3}$ It applies to practices before, during or

1 On this see Jan Smits The Need for a European Contract Law - Empirical and Legal Perspectives (Europa Law Publishing, Groningen, 2005) 155 and following.

2 Such as the costs for the conclusion of a contract concluded across the internal borders.

3 Directive 2005/29 of 11 May 2005 concerning unfair business-to-consumer commercial practices in the internal market and amending Council Directive 84/450/EEC, Directives 97/7/EC, 98/27/EC and 2002/65/EC of the Parliament and of the Council and Regulation (EC) No 2006/2004 of the European Parliament and of the Council, OJ 2005 L 149/22. 
after a commercial transaction in relation to a product or service. ${ }^{4}$ This directive will have to be transformed into national law of the 27 member states $^{5}$ by 12 June 2007. It is the most prominent recent product of the European legislature in the field of consumer law. As opposed to the technique of minimum harmonisation applied in previous directives, ${ }^{6}$ this directive aims at total harmonisation at maximum level. Finally the paper describes how the development of European consumer law serves as a catalyst for the further development of a genuine European contract law.

\section{APPRAISAL OF THE CONTEMPORARY SOURCES OF EUROPEAN CONTRACT LAW}

This paper requires an evaluation of the current situation in Europe's contract law. First of all it is essential to distinguish three different levels of contract law: the international, the supranational, and the national level. Legal practitioners in Europe quite often face the difficult situation that more than one of the levels is relevant to one case. Therefore a clear separation of the legal sources always needs to be kept in mind.

\section{A International Level}

The Vienna Convention on International Sale of Goods (CISG) of 1980 is the most prominent example of this category. ${ }^{7}$ Having effect not only on EU member states but also on other countries in the world, it is arguable whether this convention can be regarded as one of the sources of European contract law. Since only five EU member states are not a party to this convention, most of the sales transactions between businesses of different member states are subject to the CISG, unless the parties opt out.

Therefore the courts of most member states have absorbed the substance of the CISG into their decision making. Since the CISG entered into force it has continuously motivated the national courts to use comparative techniques in the interpretation of fundamental contract law concepts. The existence of the CISG for instance facilitated a more homogeneous interpretation of some openended contract law concepts, such as impediment or reasonableness. ${ }^{8}$ Therefore it is not surprising

4 See Jules Stuyck, Evelyne Terryn and Tom van Dyck "Confidence through fairness? The new directive on unfair business-to-consumer commercial practices in the internal market" (2006) 43 CMLR 107, 142.

5 After the accession of Romania and Bulgaria on 1 January 2007 the European Union consists of 27 members.

6 The legislative technique of minimum harmonisation has been adopted eg in the Directive 97/7/EC.

7 Jan Smits The Need for a European Contract Law - Empirical and Legal Perspectives (Europa Law Publishing, Groningen, 2005) 161.

8 For the relationship between CISG and the European law of consumer sale, see Thomas Wilhelmsson "European Rules on Pre-contractual Information duties?" (2006) Special issue ERA Forum scripta iuris europaei 16,21 . 
that even the European legislature brought into play many of the CISG's principles during the creation of the Directive on the sale of consumer goods. ${ }^{9}$

\section{B Supranational Level}

The European legislature is entitled to issue binding legal provisions only if the Treaty establishing the European Community (ECT) contains a legal basis. There is no legal basis in the ECT permitting the harmonisation of contract law or consumer law in general. Apart from the European legislature there is no other political body that has the capacity to provide binding contract law. It is only within the very narrow competences contained in the ECT that the harmonisation or approximation process can take place.

As far as consumer protection is concerned article 153 of the ECT states that consumer protection requirements shall be taken into account in defining and implementing Community policies and activities. This treaty provision is therefore not suitable as a legal basis for the European legislature for the enactment of a new consumer law.

The European legislature is entitled to create new consumer law only under specific provisions such as articles 2, 3 and 95 of the ECT. These provisions play a key role for the creation of new contract and consumer law. ${ }^{10}$ Article 2 ECT contains the statement that the European Community has to promote a harmonious and balanced development of economic activities. Furthermore article 3 of the ECT outlines the features of the single market through the abolition of barriers and impediments to the free movement of goods, persons, services and capital. Therefore article 95 together with articles 2 and 3 serve as a valid legal basis for the creation of new consumer law.

But the law-making under these provisions is restricted by the requirement that the approximation of laws has to be essential for the establishment of the single market. A mere discovery of inequalities between national rules and a theoretical or abstract risk of distortions of competition or barriers to the fundamental freedoms is not sufficient to justify the choice of article 95 as a legal basis. ${ }^{11}$

The most important legislative instrument on the supranational level of substantial contract law is the directive. Directives are issued by the European legislature and then need to be implemented into national law by national legislative bodies. There have been numerous directives focusing on various details of contract law such as contracts negotiated away from business premises, ${ }^{12}$

9 Directive 99/44, OJ L 171/12.

10 For example, the Directive 2005/29/EC on Unfair Business-to-Consumer Commercial Practices is based on art 95 ECT.

11 Case C-376/98 Germany v Parliament and Council [2000] ECR I-8419 (the "Tobacco advertising Case"); on this topic see for example Stuyck, Terryn and van Dyck, above n 4, 113.

12 Directive 85/577, OJ 1986 L 382/17. 
consumer credit, ${ }^{13}$ package travel, ${ }^{14}$ unfair terms in consumer contracts, ${ }^{15}$ timeshare, ${ }^{16}$ distance contracts, ${ }^{17}$ sale of consumer goods, ${ }^{18}$ electronic commerce, ${ }^{19}$ combating late payments in commercial transactions, ${ }^{20}$ financial collateral arrangements,${ }^{21}$ and distance marketing of financial services. $^{22}$

In the field of contract law and consumer law two different types of directives have been used so far. The European legislature first applied the minimum harmonisation technique and recently switched to the type of directive that aims at total harmonisation, therefore at full harmonisation at maximum level (such as the Directive on distance marketing of financial services, and Directive on Unfair Business-to-Consumer Commercial Practices ${ }^{23}$ ).

Apart from the legislative measures in the field of consumer law, the European Commission has published various communications relating to the future of contract law in Europe. The Commission's Action Plan of 12 February 2003 includes both regulatory and non-regulatory actions. ${ }^{24}$ It tries to initiate further discussion by proposing to increase quality and the coherence of the EC acquis in the area of contract law, to promote the elaboration of EU-wide general contract terms and to examine further the opportuneness of non-sector-specific solutions such as an optional instrument in the area of European contract law. ${ }^{25}$

13 Directive 87/102, OJ 1987 L 42/48.

14 Directive 90/314, OJ 1990 L 158/59

15 Directive 93/13, OJ 1993 L 095/29.

16 Directive 94/47, OJ 1994 L 280/83.

17 Directive 97/7, OJ 1997 L 144/19.

18 Directive 99/44, OJ 1999 L 171/12.

19 Directive 2000/31, OJ 2000 L 178/1.

20 Directive 2000/35, OJ 2000 L 200/35.

21 Directive 2002/47, OJ 2002 L 168/43.

22 Directive 2002/65, OJ 2002 L 271/16.

23 Directive 2005/29, OJ 2005 L 149/22.

24 See Communication from the Commission to the European Parliament and the Council "A more coherent European Contract Law - An action plan" COM (2003) 68 final; on this document see Meyer "Auf dem Weg zu einem Europäischen Zivilgesetzbuch" (2004) Betriebsberater 1258, 1286; Basedow "Grundlagen des Europäischen Privatrechts" (2004) Juristische Schulung 89, 96; Reiner Schulze "Principi sulla conslusione dei contratti nell'Acquis Communautaire" (2005) Contratto e Impresa Europa 404.

25 See also Communication from the Commission to the European Parliament and the Council "European Contract Law and the revision of the acquis: the way forward" COM (2004) 651 final; on this document see for example Staudenmayer "Weitere Schritte im Europäischen Vertragsrecht" (2005) Europäische Zeitschrift für Wirtschaftsrecht 103. 


\section{National Level}

Within the EU there are 27 different contract law regimes. Each member state has its national legislature and its own courts interpreting the contract law while deciding on contract cases. It is possible to identify various categories of contract law regimes by means of a comparative analysis. ${ }^{26}$ Some member states (such as Germany, Italy, Austria, France) have traditional civil codes regulating the contract law among other fields of private law. These civil codes belong either to the Code Napoleon tradition (such as France, Belgium, Italy) or to the German tradition (such as Germany, Greece). Apart from these groups the Scandinavian member states (Denmark, Sweden and Finland) have their own common roots of contract law. The countries that have joined the EU recently (Slovenia, Poland, Czech Republic, Slovakia, Hungary, Estonia, Lithuania and Latvia) went through many reforms in the recent past. Apart from the contract law regimes based on statutory law, there are three others based on a common law tradition (England, Ireland, Cyprus). Some member states do not even have a uniform contract law regime but have various regimes standing next to each other (such as England, Scotland, Northern Ireland) or some regional variations within the national legal contract law system (such as Catalonia). ${ }^{27}$

\section{The Role of Private International Law}

Whenever the parties of a contract belong to the same member state, the diversity does not lead to any legal problem that needs to be resolved and thus does not create added transaction costs. Whenever more than one regime is applicable to one contract, there are rules of private international law determining which law is applicable. The main source of conflict of law rules is the EC Convention on the Law Applicable to Contractual Obligations of 1980 (Rome I Convention). ${ }^{28}$ The rules of this Convention are applicable to contractual obligations in any situation involving a choice between the laws of different states of the EU. ${ }^{29}$

A choice is generally possible under article 3 of the Rome I Convention. According to this article, a contract is to be governed by the law chosen by the parties. By their choice the parties can select the law applicable to the whole or a part of the contract. It is essential that the choice be demonstrated with reasonable certainty by the terms of the contract or the circumstances of the case.

Smits, above n 1, 156.

27 Smits, above n 1, 162.

28 OJ 1998 C 27/34 (consolidated version).

29 The Brussels Regulation (Regulation $01 / 44$ on jurisdiction and the recognition and enforcement of judgments in civil and commercial matters, OC 2001 L 12/1) deals with jurisdiction and has to be applied together with the rules of the Rome I Convention; see for example Ian Kilbey "Consumer Protection evaded via the Internet" (2005) 30 EL Rev 123, 130. 
If the parties did not choose an applicable law and no exceptions apply, the relevant law is that of the country with which the contract is most closely connected. ${ }^{30}$ The Convention presumes that the contract is most closely connected with the country where the party, who is to effect the performance which is characteristic of the contract, ${ }^{31}$ has at the time of conclusion of the contract his habitual residence, or, in the case of a corporate body, its central administration.

But there are mandatory provisions which apply even though the parties have made a choice of law. ${ }^{32}$ Article 5, for instance, applies to a contract supplying goods or services to a consumer. A requirement for the application of this rule is that the purpose of the contract must be outside of the consumer's trade or profession. Under article 5 a choice of law term contained in a B2C contract does not always have the result of depriving the consumer of the protection granted to him by the mandatory rules of his country of residence. For instance a choice of law term is void if the conclusion of the contract was preceded by a specific invitation addressed to the consumer (or by advertising) and the consumer had taken all the steps necessary for the conclusion of the contract in his country of residence. The same result is applicable if the business or its agent received the consumer's order in the consumer's country of residence. As far as sales contracts concluded between a business and a consumer are concerned, the choice of law clauses are void when the consumer travelled from his own country of residence to another country and there gave his order, provided that the consumer's journey was arranged by the seller for the purpose of inducing the consumer to buy.

This present regime creates enormous potential for legal uncertainty for parties concluding contracts over the internal borders of the EU. This is particularly evident in the field of B2C contracts; the solution adopted in the Convention leads to situations in which the law applicable to the professional and the mandatory provisions of the law applicable to the consumer are applied in parallel. In the event of a dispute, this complex solution leads to high costs of procedure that are not justified, especially considering the fact that the consumer's claim is normally very small. ${ }^{33}$

The negative economic effects resulting from this legal uncertainty need to be removed with the adoption of new legal provisions on the ground of the ECT. ${ }^{34}$ There are recent reform projects that will lead to a Regulation in the law applicable to contractual obligations ${ }^{35}$. Unfortunately, these

30 Article 4 of the Rome I Convention.

31 Such as the retailer in a sales contract.

32 See especially arts 5 and 7 .

$33 \operatorname{COM}(2005) 650$ final, 6.

35 COM (2005) 650 final; see also the "Green Paper on the Conversion of the Rome Convention of 1980 into a Community instrument and its modernisation” COM (2002) 654 (01). 
reform plans of the EC legislative organs will not be able to fully resolve the problem of legal uncertainty for the parties arising from the existence of totally different contract law regimes within the single market. ${ }^{36}$ Nevertheless there are some positive aspects about the draft Regulation, especially in the field of $\mathrm{B} 2 \mathrm{C}$ contracts where it proposes a conflict rule ${ }^{37}$ that is simpler than the one contained in the Rome I Convention.

\section{EUROPEAN CONSUMER PROTECTION POLICY}

In 1985 the first directive entered into force, which aimed at the enhancement of consumer protection standards and thus lead to the approximation of the member states' contract law regimes. ${ }^{38}$ Since then the legal documents arising from the European consumer protection policy have broadly encroached on the traditionally grown structures of the member states' contract law regimes. ${ }^{39}$ A new level of contract law outside the existing contract law systems (as ruled by the civil codes or the common law) was created through the duty of implementation in the member states. $^{40}$

As mentioned previously, the ECT states that consumer protection requirements shall be taken into account in defining and implementing Community policies and activities. ${ }^{41}$ There is no "constitutional" legal provision in the ECT assigning total power to act to the European legislature. Consumer policy therefore plays a subsidiary role in the supranational law-making process. Therefore it is not surprising that the European Commission's consumer protection policy sometimes seems to be an unsystematic invasion into the domestic contract law of the EU member states. $^{42}$

The starting point for the European consumer protection policy is the idea that market integration is in the consumer interest. The aim is the amplification and the strengthening of the competition between the member states' businesses. This influence on the competition reduces the price level, increases the choice of products and services and - last but not least - enhances the

36 On the proposal see for example Peter Mankowski "Der Vorschlag für die Rom I-Verordnung (2006) 2 IPRax 101

37 See art 5

38 Directive 85/577 on contracts negotiated away from business premises, OJ 1986 L 382/17.

39 See for example Elise Poillot "Consumer and Contract Law"(2006) Special issue ERA Forum scripta iuris europaei 36.

40 As an example for this phenomenon the implementation of the Directive on the sale of consumer goods (Directive 99/44, OJ L 171/12) in Germany will be discussed later in this paper.

41 Article 153 of the ECT.

42 Klaus Peter Berger "Harmonisation of European Contract Law - The Influence Of Comparative Law" (2001) 50 ICLQ 877. 
quality of business performance. Therefore there is a necessity to approximate the laws of the member states wherever these laws are able to distort the fair competition between businesses based in different member states. Apart from other fields of law that are also highly relevant, ${ }^{43}$ the legal provisions regarding consumer protection play a key role in this debate. Generally the relationship between a business and a consumer is enclosed in and framed by a bilateral contract between them. Therefore it is natural that the European consumer policy focuses mainly on contract law: on the way in which businesses approach the consumer, on the pre-contractual information duties, ${ }^{44}$ on the means of conclusion of a contract, on the performance of the business, on the withdrawal from the contract.

All in all the consumer policy needs to be regarded as a servant of the single market and thus as a field of law-making that is subsidiary to competition law. This idea can easily be confirmed through the wording of article 153 of the TEC which states that "Consumer protection requirements shall be taken into account in defining and implementing other Community policies and activities".

\section{INSTRUMENTS OF CONSUMER PROTECTION IN THE CONTRACTUAL RELATIONSHIP}

The supranational layer of consumer protection in the contractual relationship is very similar to the one adopted within the national regimes of the member states. A comparative analysis of the instruments used by the legislatures in order to protect the consumer from the risks that typically exist in a contractual relationship proves this similarity. The examples of conformity, immanent right of withdrawal and form requirements that will be briefly discussed now show that the techniques of consumer protection in the contractual relationship can be regarded as a common denominator of the contract law regimes of the member states. ${ }^{45}$

\section{A Conformity}

First of all the duty to bring goods or services into conformity with a contract exists in all the member states on the national level and on the supranational level (eg the directive on sale of consumer goods, ${ }^{46}$ the directive on package travel ${ }^{47}$ ). The implementation of article 2 of the directive on the sale of consumer goods has to be considered as a very important milestone on the way to a uniform European contract law. According to this provision "the seller must deliver goods to the consumer, which are in conformity with the contract of sale". The conformity therefore follows the scheme of subjective standards rather than objective criteria. This example is

43 Such as environmental law, labour law, company law.

44 Some details of these pre-contractual information duties will be discussed later in this paper.

45 See for example Poillot, above n 39, 39.

46 Directive 99/44, OJ 1999 L 171/12.

47 Directive 90/314, OJ 1990 L 158/59. 
particularly stunning for the UK where traditionally common law rules created for trade used to be applied to B2C-contracts: therefore goods within a B2C-contract had to be only of merchantable quality. ${ }^{48}$ The new term of satisfactory quality, therefore a quality that meets the customer's expectations, now applies not only to $\mathrm{B} 2 \mathrm{C}$ but also to $\mathrm{B} 2 \mathrm{~B}^{49}$ sales. ${ }^{50}$

\section{B Immanent Right of Withdrawal}

The right of withdrawal as contained, for example, in the directives on contracts negotiated away from business premises, ${ }^{51}$ consumer credit, ${ }^{52}$ timeshares, ${ }^{53}$ distance contracts, ${ }^{54}$ distance marketing of financial services ${ }^{55}$ is a central aspect of contract law within the European consumer law. The so-called immanent right of withdrawal, that protects the consumer even in cases where the product or service is in conformity with the contractual agreement, fulfils many possible goals of consumer policy. The right of withdrawal can be part of marketing strategies, sometimes helps to safeguard the weaker party's rights or to counterbalance the unilateral mistake of a party. ${ }^{56}$

\section{Form requirements}

It is part of the European tradition to protect the consumer by establishing detailed form requirements and sanctions against the other contract party in case of violation of those requirements. Thus it is not surprising that the European legislature has used this technique to further protect the consumer in its supranational law-making efforts. The directives on contracts negotiated away from business premises,${ }^{57}$ on consumer credit, ${ }^{58}$ on timeshares, ${ }^{59}$ on distance contracts, ${ }^{60}$ on distance marketing of financial services ${ }^{61}$ and so on contain various form

48 Geraint Howells "Consumer Protection and European Contract Law Harmonisation" (2006) Special issue ERA Forum scripta iuris europaei 45.

49 Business to business.

50 Nevertheless the term of satisfactory quality is mandatory only in the B2C context.

51 Directive 85/577, OJ 1986 L 382/17.

52 Directive 87/102, OJ 1987 L 42/48.

53 Directive 94/47, OJ 1994 L 280/83.

54 Directive 97/7, OJ 1997 L 144/19.

Directive 2002/65, OJ 2002 L 271/16.

6 See Francesco A Schurr Geschäftsimmanente Abstandnahme (Mohr, Tübingen, 2006) 191 and following.

7 Directive 85/577, OJ 1986 L 382/17.

8 Directive 87/102, OJ 1987 L 42/48.

9 Directive 94/47, OJ 1994 L 280/83.

60 Directive 97/7, OJ 1997 L 144/19.

61 Directive 2002/65, OJ 2002 L 271/16. 
requirements that sometimes make it hard for businesses to approach the consumer without violating these standards. These form requirements often have been criticised as being too harsh and sometimes even as against the interests of the consumer. ${ }^{62}$

\section{THE RELEVANCE OF PRE-CONTRACTUAL INFORMATION DUTIES}

In order to further explain the connection and correlation between consumer law and contract law, pre-contractual information as one of the most important consumer protection instruments mentioned previously in this paper will now be considered. Various EC directives, that had a strong influence on the member states' contract law regimes, contain rules regarding such information duties imposed on the businesses; ${ }^{63}$ pre-contractual information duties are therefore part of the acquis communautaire. ${ }^{64}$

The European legislature pursues various goals when creating these pre-contractual information duties, such as monitoring of the fairness of the parties' contracting behaviour, safeguarding the authenticity of the consent as well as creating suitable tools for coherent market behaviour. Many European consumer law directives contain long lists of informational items that have to be provided by the business in order to safeguard the consumer as the weaker party. Especially, the directive on distance marketing of financial services ${ }^{65}$ and the timeshare directive ${ }^{66}$ rely heavily on information as an instrument for enhancing the status of the consumer as contract party. The consumer protection directives therefore have a strong impact on the transparency of contracts.

\section{DIRECTIVE 2005/29/EC ON UNFAIR BUSINESS-TO-CONSUMER COMMERCIAL PRACTICES}

The transparency of contracts is also a key aspect of the Directive on Unfair Business-toConsumer Commercial Practices (hereinafter UCPD). ${ }^{67}$ Article 7 of this directive bans the

62 For example, if the consumer buys a product at a very good price. In such a situation it is sometimes against the interests of the consumer if the contract is void due to the violation of form requirements: see Helmut Heiss Formmängel und ihre Sanktionen (Mohr, Tübingen, 1999).

63 Such as Directive 85/577, OJ 1986 L 382/17; Directive 87/102, OJ 1987 L 42/48; Directive 90/314, OJ 1990 L 158/59; Directive 97/7, OJ 1997 L 144/19; Directive 99/44, OJ 1999 L 171/12.

64 Thomas Wilhelmsson "European Rules on Pre-contractual Information duties?" (2006) Special issue ERA Forum scripta iuris europaei 16.

65 Directive 2002/65, OJ 2002 L 271/16.

66 Directive 94/47, OJ 1994 L 280/83.

67 The directive needs to be implemented by 12 June 2007 . 
misleading omission of information. ${ }^{68}$ Thus it contains an indirect duty on the business to disclose information. ${ }^{69}$

The aim of the UCPD is very similar to that of those discussed previously in this paper therefore to encourage consumers to actually make transactions across the internal borders. The UCPD aims at the completion of the internal market. Generally speaking this directive applies to B2C-practices before, during or after a commercial transaction in relation to a product or service. ${ }^{70}$

The UCPD is without any doubt one of the most important milestones on the road towards a harmonised contract and consumer protection law in the EC. The directive is based on the principle of fairness. According to the directive the behaviour of every business needs to conform to the farreaching standard of fairness contained in the directive.

For the purpose of this article it is relevant to figure out the impact of the UCPD on the development of European contract law. Article 3 (2) provides that the directive operates without prejudice to contract rules such as the validity, formation or effect of a contract. There are nevertheless strong links between the European contract law and the contract law regimes of the member states on one hand and the UCPD on the other. This depends especially on the fact that the substance of this directive is not limited to the pre-contractual sphere. Especially the previously mentioned article 7 of the UCPD (according to which a commercial practice shall be regarded as misleading if it omits material information that the average consumer needs to take an informed transactional decision and thereby causes or is likely to cause the average consumer to take a transactional decision that would not have been taken otherwise) has a strong impact on the status quo of the European contract law standards. The implementation of the UCPD in the member states will enormously improve the chances of the consumer to avoid a contract by arguing lack of consent.

\section{CONSUMER LAW AS A CATALYST OF CONTRACT LAW INTEGRATION}

In order to reach a deeper understanding of the connection and correlation between consumer law and contract law, the paper now briefly explains how the European consumer protection directives serve - in the phase of their implementation in the member states - as catalysts for the

68 See article 7(1): A commercial practice shall be regarded as misleading if, in its factual context, taking account of all its features and circumstances and the limitations of the communication medium, it omits material information that the average consumer needs, according to the context, to take an informed transactional decision and thereby causes or likely to cause the average consumer to take a transactional decision that he would not have taken otherwise.

69 Thomas Wilhelmsson "European Rules on Pre-contractual Information duties?" (2006) Special issue ERA Forum scripta iuris europaei 16, 22.

70 See Stuyck, Terryn and van Dyck, above n 4, 142. 
development of genuine European contract law even beyond the boundaries of B2C contracts and thus beyond the limits of power to act of the European legislature under the ECT.

This phenomenon can easily be explained with the example of the implementation of the directive on the sale of consumer goods ${ }^{71}$ in Germany. ${ }^{72}$ Unlike previous consumer law directives, the directive on the sale of consumer goods did not focus just on some details but had a strong impact on fundamental values of the member states' national contract law regimes. Therefore it was hard for the national legislatures to finally implement it without totally altering and deforming their national contract law environment.

As far as the substance was concerned the modification which this directive introduced to national contract law in order to improve consumer protection, necessitated at least some compensation for the commercial parties. The German legislature - along with the law-making organs of various other member states ${ }^{73}$ - used the technique of "extensive implementation" in order to create this kind of compensation for the commercial parties. The meaning of "extensive implementation" is that the national legislature goes beyond the original scope of the subject-matter contained in the directive. Even though the directive created binding law in the constellation of $\mathrm{B} 2 \mathrm{C}$-contracts only, the protection of the buyer was extended by the German legislature to B2B and $\mathrm{C} 2 \mathrm{C}^{74}$-contracts. ${ }^{75}$ Thus the European legislature succeeded in the political goal of harmonising the law of sales of goods for all types of sales. This result is quite stunning considering the fact that under the ECT the European legislature has power to approximate the law of B2C sales contracts only.

\section{CONCLUSION}

Legal diversity between the contract law regimes of the member states is a risk for businesses acting across the internal borders and thus hinders the expansion of businesses within the single market. Especially, small and medium-sized enterprises cannot cope with the high costs of legal advice in other member states, whereas large enterprises can afford such extra costs. It should therefore be on the "priority list" of the European legislature to remove the legal walls that have

71 Directive 99/44, OJ L 171/12.

72 Klaus Peter Berger "Harmonisation of European Contract Law - The Influence of Comparative Law" (2001) 50 ICLQ 877.

73 For the UK see Howells, above n 48, 45.

74 Consumer to consumer.

75 Poillot, above n 39, 42. 
been built up over the centuries in which the different contract law traditions have grown in the member states. ${ }^{76}$ An early move towards a European contract law would thus support the main consumer interests, such as the reduction of the price level, the increase of choice between various products and services and the enhancement of the products' and services' quality.

76 The idea envisaged by the European Commission, in which regulatory and non-regulatory measures should be taken in order to create a more coherent European contract law, could lead to a fast achievement of this result; see Communication from the Commission to the European Parliament and the Council "A more coherent European Contract Law - An action plan" COM (2003) 68 final, 14. 